\title{
Analysis of Severe Accident in Complex System Reactor Using Moving Particle Semi-Implicit (MPS) Method
}

\author{
Rifqa Fikriya Rahasri ${ }^{1}$, Asril Pramutadi Andi Mustari ${ }^{2}$, Anni Nuril Hidayati ${ }^{1}$ \\ ${ }^{1}$ Physics Department, Faculty of Mathematics and Natural Science, Bandung Institute of Technology, Jalan Ganesha 10, Bandung \\ 40132, Indonesia \\ ${ }^{2}$ Nuclear Physics and Biophysics Research Division, Physics Department, Faculty of Mathematics and Natural Science, Bandung \\ Institute of Technology, Jalan Ganesha 10, Bandung 40132, Indonesia
}

\begin{tabular}{|c|c|}
\hline ARTICLE INFORMATION & ABSTRACT \\
\hline $\begin{array}{l}\text { Article History: } \\
\text { Received: } \\
29 \text { November } 2021 \\
\text { Received in revised form: } \\
\text { 30 December } 2021 \\
\text { Accepted: } \\
\text { 31 December } 2021\end{array}$ & $\begin{array}{l}\text { ANALYSIS OF SEVERE ACCIDENT IN COMPLEX SYSTEM REACTOR USING MOVING } \\
\text { PARTICLE SEMI-IMPLICIT (MPS) METHOD. The very complex structure of nuclear reactors is } \\
\text { one aspect of the cause of severe accidents in nuclear reactors. To prevent serious accidents, } \\
\text { analysis is needed on the reactor design before the reactor is built. Reactor accident analysis can } \\
\text { be done using the Moving Particle Semi-Implicit method. The Moving Particle Semi-Implicit } \\
\text { method is excellent in simulating the movement of liquid fuel in a reactor because it can analyze } \\
\text { the free surface flow of an incompressible liquid without using a mesh grid. Simulations were } \\
\text { carried out using three types of fluids with different viscosities and densities such as water, oil, } \\
\text { and wax. The simulation results show that the water takes the fastest time to drain all the particles } \\
\text { and the oil takes the longest time. From the simulation results, it can be determined that the } \\
\text { kinematic viscosity of a liquid affects its flow velocity. }\end{array}$ \\
\hline $\begin{array}{l}\text { Keyword: } \\
\text { Severe Accident } \\
\text { Reactor Accident } \\
\text { MPS }\end{array}$ & $\begin{array}{l}\text { ABSTRAK } \\
\text { ANALISIS KECELAKAAN PARAH PADA REAKTOR DENGAN SISTEM YANG KOMPLEKS } \\
\text { MENGGUNAKAN METODE MOVING PARTICLE SEMI-IMPLICIT (MPS). Struktur reaktor nuklir } \\
\text { yang sangat kompleks berpotensi menjadi salah satu aspek penyebab terjadinya kecelakaan } \\
\text { parah pada reaktor nuklir. Untuk mencegah terjadinya kecelakaan parah, diperlukan analisis pada } \\
\text { desain reaktor sebelum reaktor tersebut dibangun. Analisis kecelakaan reaktor dapat dilakukan } \\
\text { menggunakan metode Moving Particle Semi-Implicit. Metode Moving Particle Semi-Implicit ini } \\
\text { sangat baik dalam mensimulasikan pergerakan bahan bakar cair dalam sebuah reaktor karena } \\
\text { dapat menganalisis aliran permukaan bebas dari cairan yang tidak termampatkan tanpa } \\
\text { menggunakan mesh grid. Simulasi dilakukan menggunakan tiga jenis cairan dengan viskositas } \\
\text { dan densitas yang berbeda yakni air, minyak dan lilin. Hasil simulasi menunjukkan bahwa air } \\
\text { membutuhkan waktu paling cepat untuk mengalirkan seluruh partikelnya dan minyak } \\
\text { membutuhkan waktu paling lama. Dari hasil simulasi yang dilakukan, dapat disimpulkan bahwa } \\
\text { viskositas kinematika dari sebuah cairan mempengaruhi kecepatan alirannya. } \\
\text { Kata kunci: Kecelakaan parah, Kecelakaan reaktor, MPS }\end{array}$ \\
\hline
\end{tabular}

\section{INTRODUCTION}

Until now, the construction of nuclear reactors is still a matter of concern to the general public considering the impact caused during a nuclear accident. Since the initial construction of the nuclear reactor, there have been three major accidents, namely the Three Miles Island event (United States) in 1979, the Chernobyl event in Ukraine in 1986, and the Fukushima incident in Japan in 2011.

As an example of the three nuclear accidents, the Three Miles Island unit 2 nuclear reactor accident was the lightest accident because it did not cause any casualties. This

*Penulis korespondensi.

E-mail: rifqafikriya@gmail.com accident was caused by the malfunction of the main pump of the secondary cooling system,

causing an increase in temperature and melting of the fuel in the reactor core[1]. Although there were no fatalities, the TMI-2 accident still caused financial losses.

To prevent such an event from happening again, research related to reactor design is needed. Complex nuclear reactor designs make engineers have to continue to research the potential for accidents and improve the design [2].

One of the causes of nuclear reactor accidents is the melting of the core. For this reason, research is needed regarding fluid 
behavior during an accident. Research has been carried out regarding the interaction of melted uranium with the power cable penetration channel on the BWR during a severe accident by Wulandari [3]. In that study, Wulandari simulated fluid flow using the MPS-LER method to analyze the interactions that occur between uranium and the electric tube at the bottom of the BWR. After conducting simulations with MPS-LER, he also conducted experiments using the same fluid, namely water, and wax [3].

The Moving Particle Semi-Implicit (MPS) method was first introduced by Koshizuka and Oka in 1996[4]. This method can analyze the free surface flow of incompressible liquids without a mesh grid so that it is suitable for simulating the movement of molten fuel in the reactor core [5].

The purpose of this research is to analyze the core melting process, in terms of relocation, during a reactor accident. The simulation process, i.e., pressure distribution, is carried out using three fluids namely water, oil, and wax. The three fluids are used because they have different kinematic viscosity and densities.

\section{MOVING PARTICLE SEMI-IMPLICIT}

The Moving Particle Semi-Implicit (MPS) method is one method that can simulate the phenomenon of flow motion. The MPS method can analyze the free surface flow of incompressible liquids without using a mesh grid so that it is very good at simulating the movement of molten fuel in the reactor core[6]. This method can solve the NavierStokes equation in the Lagrangian framework. The method applied consists of splitting the time step into two steps and correction. The fluid is represented by particles and the motion of each particle is calculated based on the interaction with neighboring particles via a Kernel function.

In this case, we use an incompressible fluid. The equation governing incompressible flow is the continuity equation and the NavierStokes equation is as follows:

$\frac{d \rho}{d t}=0$
$\frac{D \rho}{D t}=-\frac{1}{r h o} P+v \nabla^{2} \mathbf{u}+\boldsymbol{g}$

Where $\rho$ is the density, $\mathrm{t}$ is the time, $\mathbf{u}$ is velocity vector, $\nabla$ is the gradient, $\mathrm{P}$ is pressure, $V$ is the kinematic viscousity dan $\boldsymbol{g}$ is gravity. In the left side of Navier-Stokes equation 1 and 2 represents the Lagrangian diferentiation.

The interaction between particles showed as kernel function where $r$ represents the distance between particles and $r_{e}$ is an effective range from particle interaction. Kernel function can be shown as follows the equation 3.

$w(r)= \begin{cases}\frac{r_{e}}{r}-1\left(0 \leq r<r_{e}\right) \\ 0 \quad(r \leq r)\end{cases}$

If the distance between particles is greater than the effective range of particle interaction, then the Kernel function becomes zero. The Kernel function's graph can be shown in Figure 1.

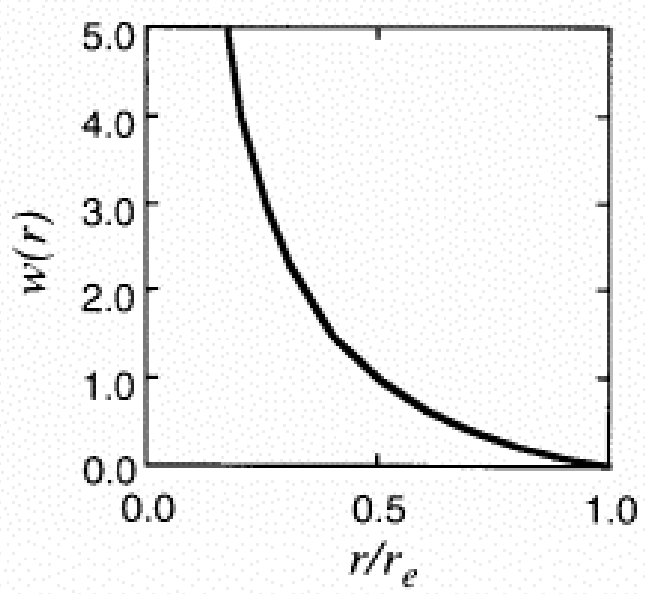

Figure 1. Kernel function's graph [1].

The density of the number of particles which is proportional to the density of the liquid when the position of the particle $i$ can be approximated by equation 4 .

$\mathrm{n}_{\mathrm{i}}=\sum_{j \neq i} w\left(\left|r_{j}-r_{i}\right|\right)$

Where $r_{j}$ and $r_{i}$ are position vectors of particles $j$ and $i$. For Gradient, Divergence and Laplacian can be discretized using equation (5) to (7).

$<\nabla \phi>_{i j}=\frac{\left(\phi_{j}-\phi_{i}\right)\left(r_{j}-r_{i}\right)}{\left|r_{j}-r_{i}\right|^{2}}$ 


$$
\begin{aligned}
& <\nabla \phi>_{i}=\frac{d}{n^{0}} \sum_{j \neq i} w\left(\left|r_{j}-r_{i}\right|\right) \frac{\left(\phi_{j}-\phi_{i}\right)\left(r_{j}-r_{i}\right)}{\left|r_{j}-r_{i}\right|^{2}} \\
& <\nabla^{2} \phi>_{i}=\frac{2 d}{\lambda n^{0}} \sum_{j \neq i} w\left(\left|r_{j}-r_{i}\right|\right)\left(\phi_{j}-\phi_{i}\right)
\end{aligned}
$$

Where $d$ is the number of dimensions, $n^{0}$ is the density of the number of particles that are suitable for an incompressible system, and $\lambda$ is the parameter for obtaining results comparable to the analytical solution. The value of $\lambda$ can be approximated by using the equation 8 .

$$
\lambda=\frac{\sum_{j \neq i} w\left(\left|r_{j}-r_{i}\right|\right)\left|r_{j}-r_{i}\right|^{2}}{\sum_{j \neq i} w\left(\left|r_{j}-r_{i}\right|\right)} \cong \frac{\int_{v} w(r) r^{2} d v}{\int_{v} w(r) d v}
$$

\section{METHOD}

Simulation is done by varying the type of fluid based on its viscosity and kinematic density. In this experiment, water, oil, and paraffin wax will be used. The number of fluid particles to be simulated is 390 particles. The tools and materials used in this experiment are two containers to accommodate fluids, pipes and plates in the form of a ladder. The arrangement of tools and materials can be seen in Figure 2. The arrangement of the tools was done digitally using the Microsoft Excel. The simulation results can be seen using MPS application.

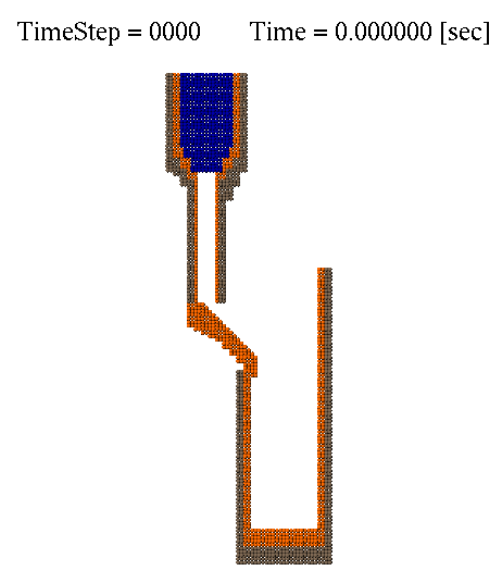

Figure 2. Simulation preliminary design.

\section{RESULT AND DISCUSSION}

The process of moving the water fluid can be seen in Figure 3. The water fluid begins to touch the plate at the 6th second and begins to touch the wall at the 10th second. Furthermore, at the 13th second the water has touched the bottom of the container. Flowing water particles tend to be scattered and not closely spaced. When water particles hit a wall or container, the reflection is quite strong, it can be seen in the relocation process of 13 to 16 seconds. The time it takes for all the water particles to fill the bottom container is 54 seconds.

Unlike water, the oil relocation process takes a slower time. The oil takes 66 seconds to drain all the particles to the bottom of the container. The shape of the flow of oil particles looks denser (the distance between the particles is very close) it can be seen in the flow at 13-30 seconds. When touching a wall surface or the bottom of the container, the reflection of the particles is not too strong. At the end of the simulation, there is 1 particle that does not flow into the container. The oil relocation process can be seen in Figure 4.

The wax relocation process can be seen in Figure 5, the process takes time which is not much different from water. Water takes 54 seconds while candles take 56 seconds to move all the particles from top to bottom. The shape of the wax fluid flow is quite tenuous but not too tenuous like water which can be seen in timesteps 12 to 16 . Timesteps 12 and 16 also describe events when the fluid hits a surface. From the picture, it can be seen that the reflection of the wax particles is not too strong when compared to water but stronger when compared to water.

Figure 6 is a pressure profile of the water relocation process. In timestep 1 , all water particles in the upper container have 4 different color variations, namely red, yellow, green, and blue. Furthermore, in timestep 6 the pressure profile changes to 2 colors, namely green and blue only. In timestep 7, yellow and red colors appear at the collision places, such as the meeting between the pipe and the connecting plate. In timestep 10 to 16 , there are various color variations as before in the pile of particles in the pipe. The particles that hit the walls also change color. At the 30th timestep, the particles have filled the container so much that they collide with a light force, causing the particles to change from blue to green. 



TimeStep $=0040 \quad$ Time $=0.400135[\mathrm{sec}]$

Figure 3. Water relocation process. 

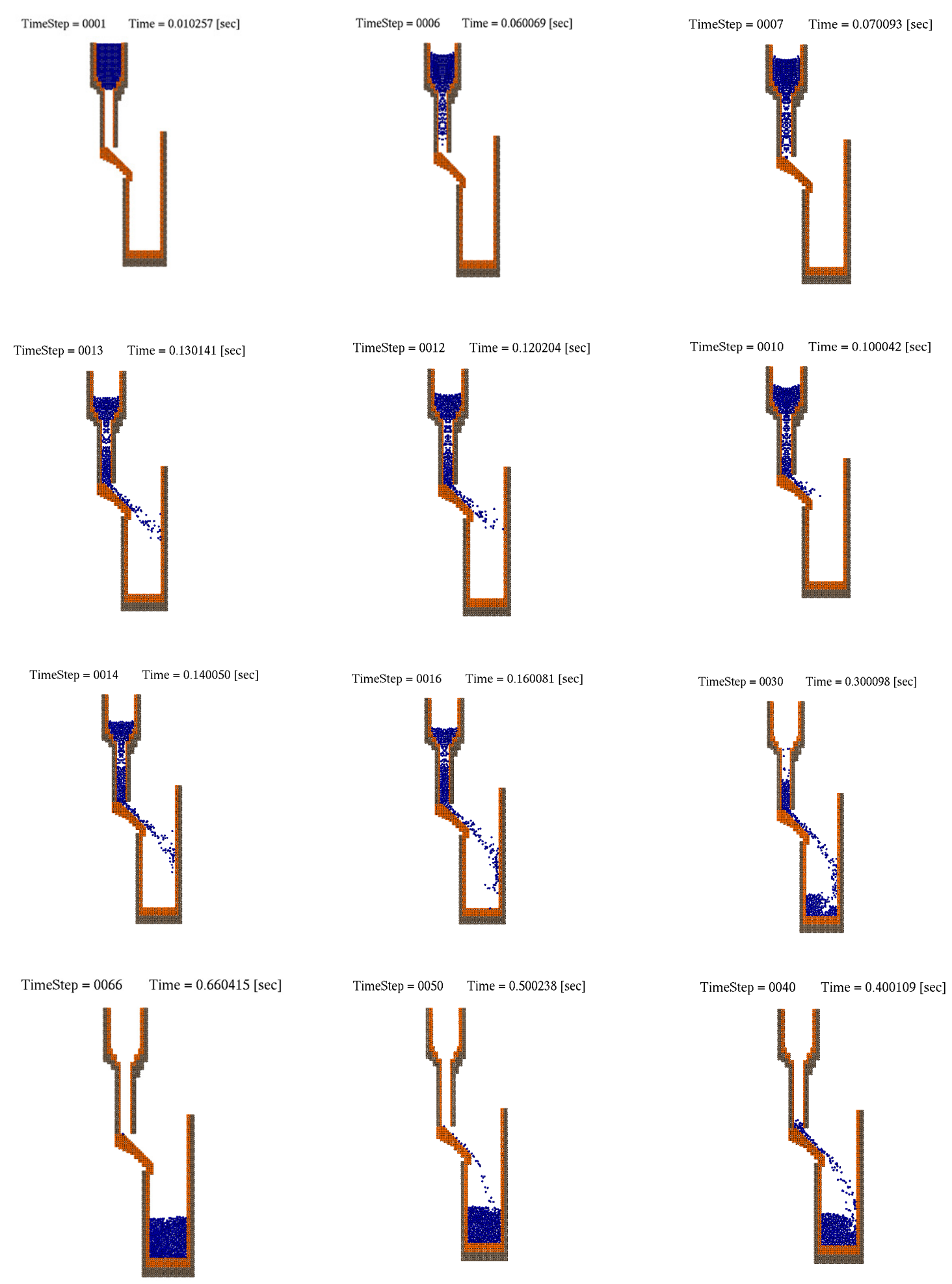

Figure 4. Oil relocation process. 

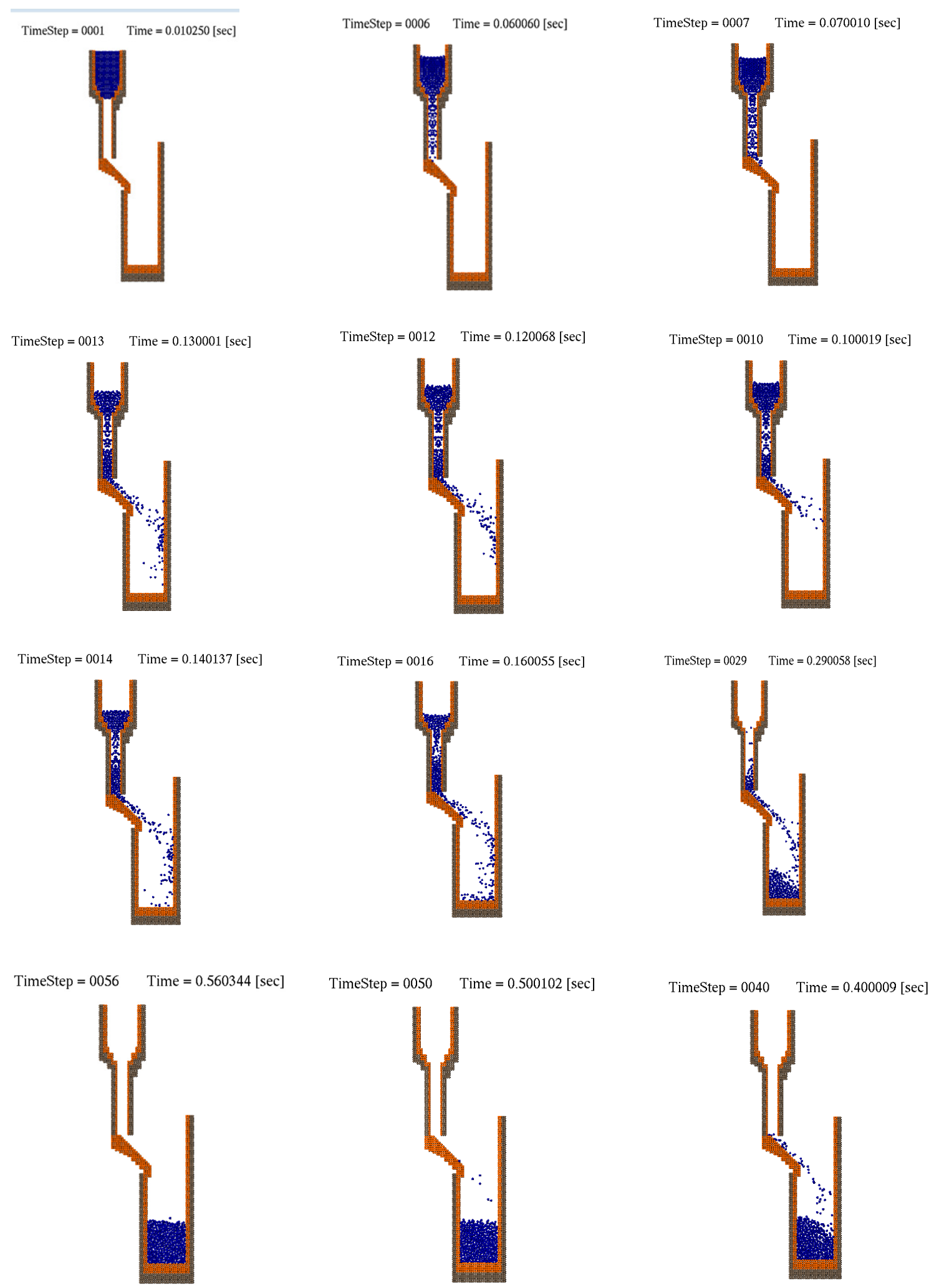

Figure 5. Candle wax relocation process. 



TimeStep $=0054 \quad$ Time $=0.540089[\mathrm{sec}]$
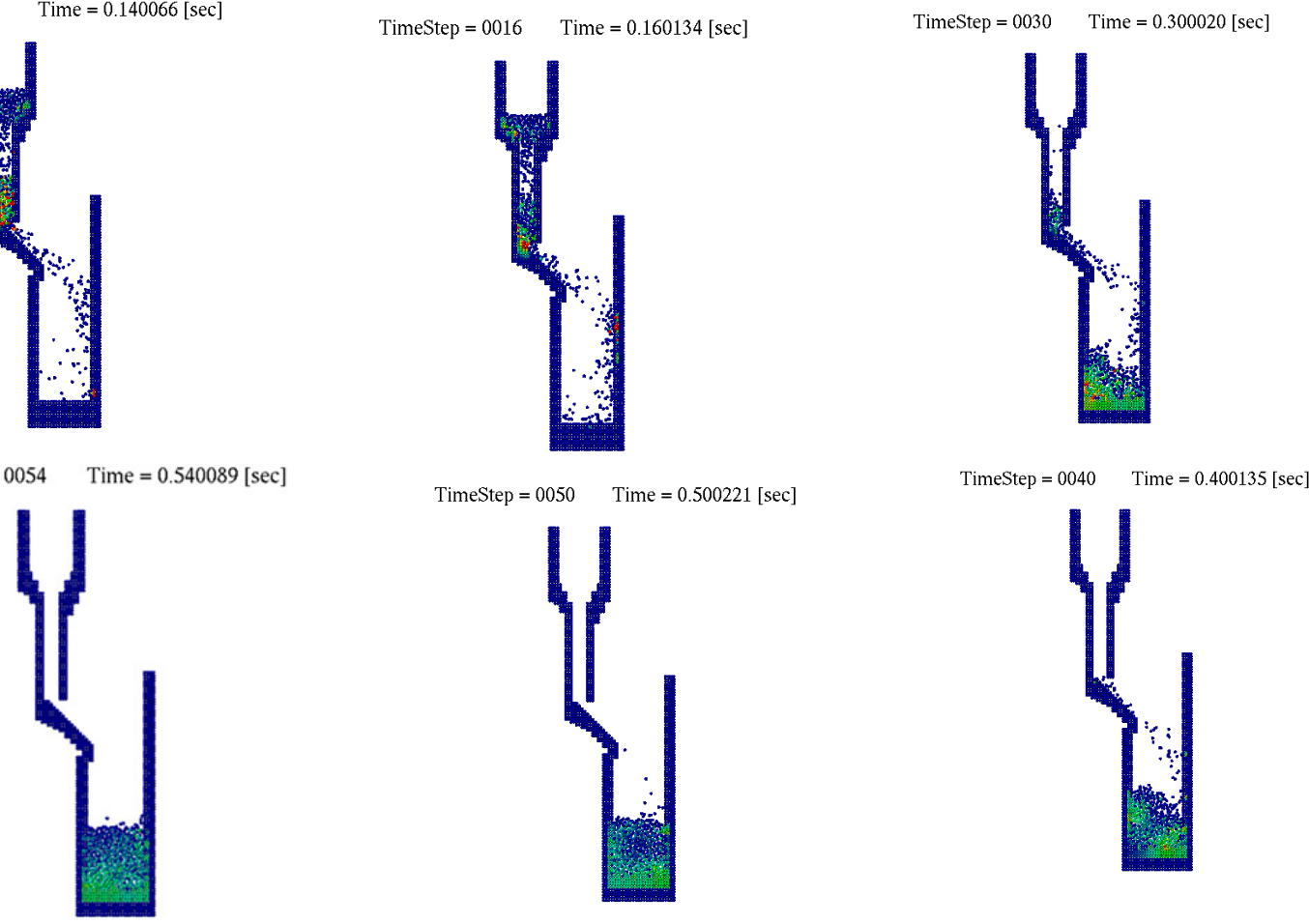

Figure 6. Pressure Profile of Water relocation process. 
Figure 7 is the pressure profile of the oil relocation process. In timestep 1 , all oil particles in the upper container have 4 different color variations, namely red, yellow, green, and blue. Furthermore, in timestep 6 the pressure profile changes to 2 colors, namely green and blue only. In timestep 7, yellow and red appear in the area between the top container and the pipe. In timestep 10, the number of yellow and red particles is increasing in the same place as in timestep 7, but there is an additional color change in the connecting part between the pipe and the slab. In the 12th timestep, the red and yellow particles are reduced and turn green so that at this timestep, the color of the particles is dominated by green.

Then, at the 13th and 14 th timesteps, the particles with red and yellow colors have started to appear again. In timestep 16, the oil particles have begun to touch the bottom of the bottom container, causing a change in the color of the particles from blue to red and green. At the 30th timestep, the color of the pressure profile of the particles changed from red to predominantly green. At timestep 40 until the end of the simulation, the pressure profile color is still dominated by green and yellow.

The pressure profile of the wax fluid relocation can be seen in Figure 8. From the picture, it can be seen that in timestep 1 the pressure profile color is the same as in water and oil with a combination of 4 colors. In timestep 6 and 7 , the color of the pressure profile in the upper container is dominated by green.

Next, at timestep 10 when the particles have started to touch the wall, the color of the pressure profile of the particles in the upper container is dominated by green, while at the junction between the pipe and the slab is dominated by red. In timestep 12-14, the color of the pressure profile at the junction of the pipe and slab becomes varied. This shows that the particle pressure in the area has begun to decrease. Then, in timestep 16-40, there are 4 variations of particle color with the dominance of green. In timestep 50-56, there are only 2 variations of the pressure profile color of the candle with the dominant color being green.
From the three simulations carried out, it can be seen that the flow pattern of water fluid has a more tenuous shape (the distance between the particles is farther) when compared to wax and oil fluids. This is due to the lower kinematic viscosity of water among the three fluids. Water has a kinematic viscosity of $1.004 \times 10^{-6} \mathrm{~m}^{2} / \mathrm{s}$ and the reflection of particles hitting a surface is also seen farther away.

For oil fluids, the flow of particles has the most neatly arranged pattern (the distance between the particles is very close) when compared to water and wax. The flow of oil particles also takes the slowest time to reach the bottom container. This is caused by the kinematic viscosity of the oil which has the greatest value, namely $54.89 \mathrm{E}-06$. Among the three fluids, only the oil fluid does not all fall into the bottom container. The oil leaves a particle on the plate.

Wax fluids have a flow pattern similar to water because their kinematic viscosities are not much different. The difference between the two lies in the oscillation of the particles. In the simulation results with pressure profile images, it can be seen that before the end of the simulation the color of the pressure profile candles is still very varied.

The simulation results of the three fluids when all the particles have fallen into the bottom container can be seen in Table 1 . Then, from the table, a graph can be made as shown in Figure 9.

Table 1. Time step data and number of particles

\begin{tabular}{ccc}
\hline Fluid & Timestep & Number of particles \\
\hline Water & 54 & 390 \\
Oil & 66 & 389 \\
Paraffin Wax & 56 & 390 \\
\hline
\end{tabular}

The kinematic viscosity of a fluid affects the particle flow pattern of the fluid. This statement can be proven from our experiments. The fluid flow pattern of water has a loose shape or the distance between the particles is farther, followed by wax and oil. which proves that the kinematic viscosity is the smallest among the three fluids. 

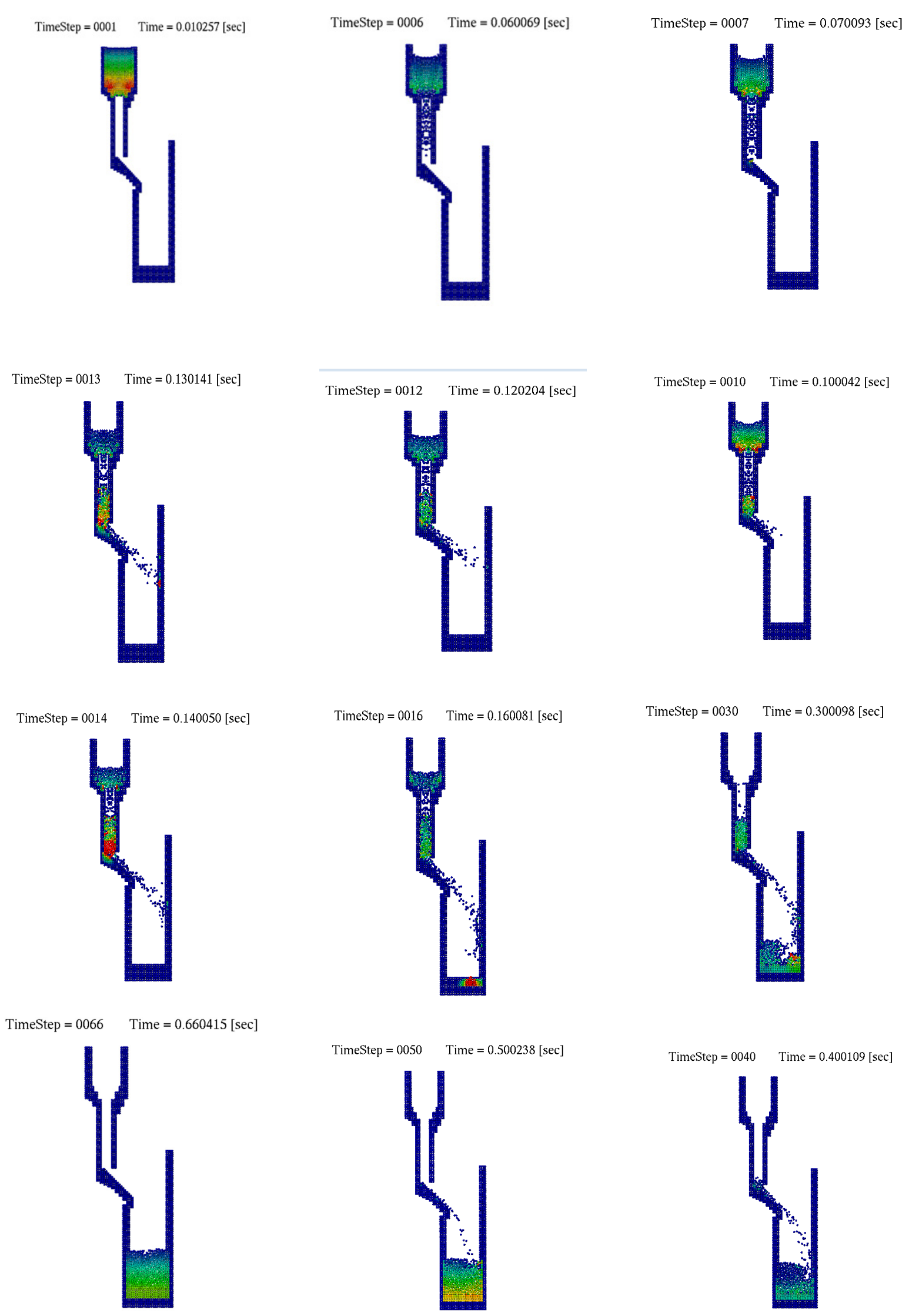

Figure 7. Pressure Profile of Oil relocation process. 

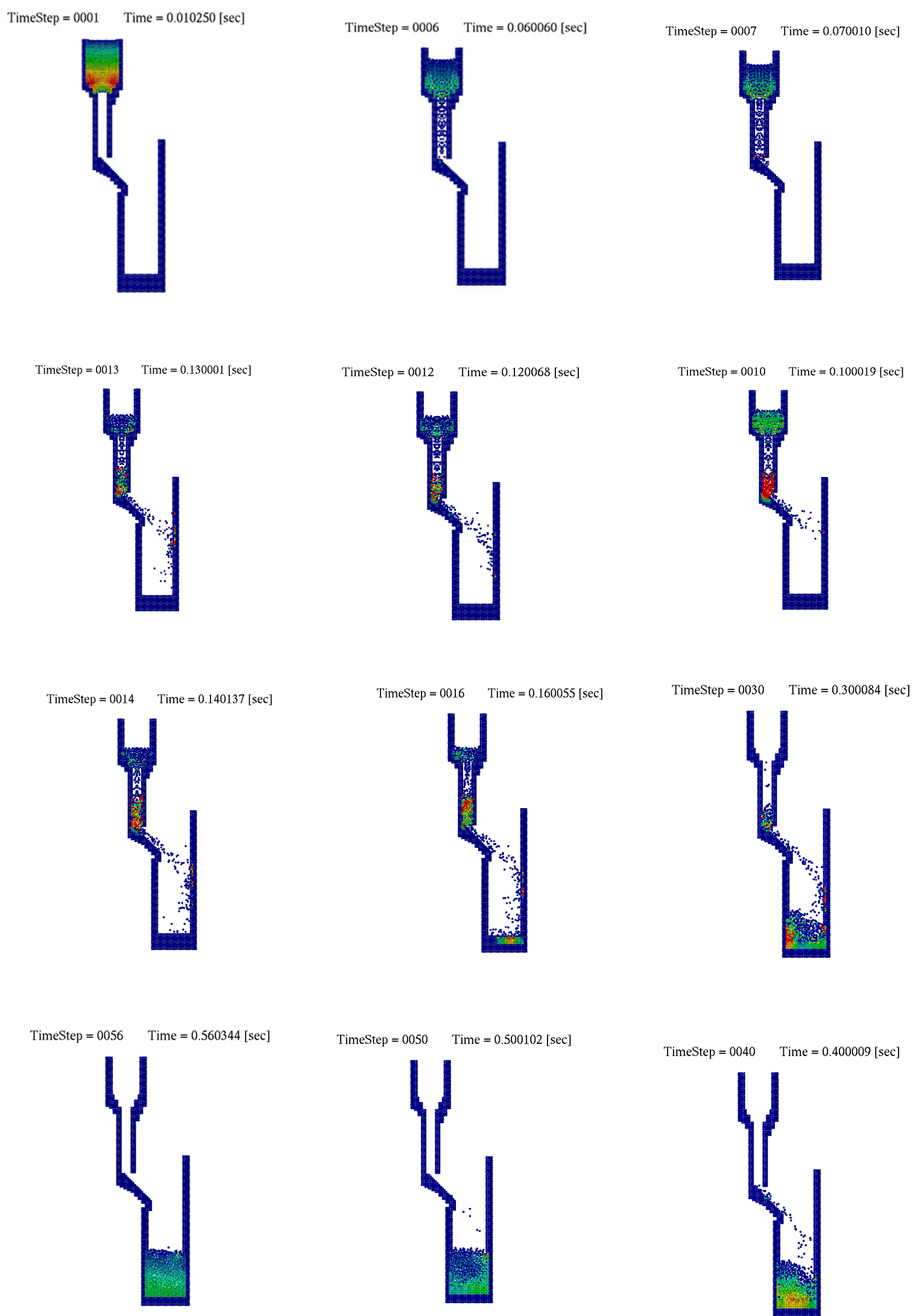

Figure 8. Pressure Profile of Candle Wax relocation process. 


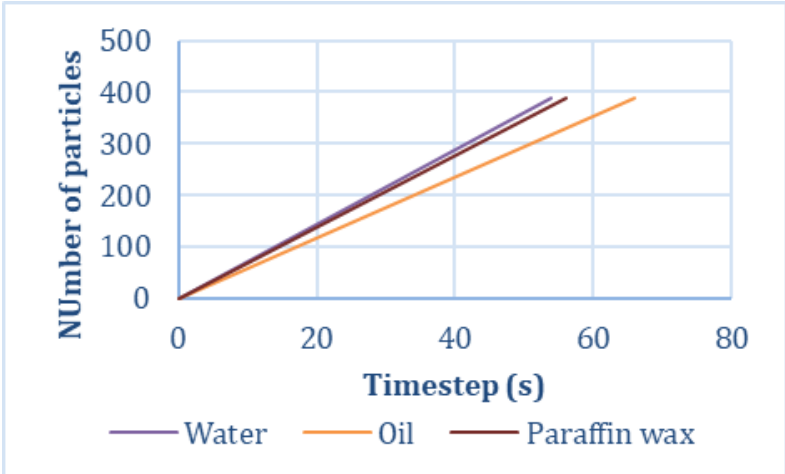

Figure 9. Particle Time Graph When Entering Lower Tank.

\section{CONCLUSION}

In this experiment, the method used to simulate the momentum process between the fluid and the plate is Moving Particle SemiImplicit (MPS). Three types of fluids are used with different kinematic viscosity and density values, namely water, oil, and wax.

From the simulation, it can be seen that the kinematic viscosity of the fluid affects the velocity of the fluid. In this simulation, the slowest flow velocity is oil fluid. In contrast, water and wax have almost the same flow velocity. This follows the theory that the viscosity of a fluid is inversely proportional to its flow velocity. Because of the three fluids, oil has the highest kinematic viscosity value, so oil also has the slowest flow.

In addition to flow velocity, this simulation can also present the process of fluid momentum with the slab. Of the three fluids, the momentum of the wax particles is the strongest.

\section{ACKNOWLEDGMENT}

This study is fully funded by P2MI of Institut Teknologi Bandung 2021, Indonesia. The authors wish to thank Professor S. Koshizuka, Professor M. Sakai, and Dr. K. Shibata of University of Tokyo for helpful comments and providing the basics MPS code for fluids.

\section{REFERENCES}

[1]. Nurma'rifah, Wuri. 2019. “Analisis Kecelakaan Nuklir Reaktor Three Mile Island Dengan Aplikasi Pctran 2loop Pwr Simulator Dan Skenario Meminimalisir Dampaknya"

[2]. Webster, Craig S. 2016. "Safety in unpredictable complex systems - a framework for the analysis of safety derived from the nuclear power industry". Promotheus 2-19

[3]. Wulandari, Rindi, Sutanto, Asril Pramutadi Andi. 2017. "Interaction Of Molten Uranium With Electrical Tube Of A Bwr During Severe Accident" Jurnal Iptek Nuklir Ganendra 1-8

[4]. S. Koshizuka dan Y. Oka. 1996. "Moving-Particle Semi-Implicit Method for Fragmentation of Incompressible Fluid." Nuclear Science and Engineering 1-14.

[5]. Lubis, Nur Azizah. 2018. "Pengaruh Kekentalan Cairan Terhadap Waktu." Jurnal Ilmu Fisika dan Teknologi 2.

[6]. Ilham, Muhammad, Yacobus Yulianto, Asril Pramutadi Andi . 2017. "Simulasi Relokasi Aliran Fluida Tak Termampatkan." SKF 1-13. 